\title{
DNA Image Cytometry
}

National Cancer Institute

\section{Source}

National Cancer Institute. DNA Image Cytometry. NCI Thesaurus. Code C20098.

A technique for quantitation of cell DNA content. 